\title{
Synoptic pressure patterns associated with major wind erosion events in southern Sweden (1973-1991)
}

\author{
Marie Ekström ${ }^{1, *}$, Peter Jönsson ${ }^{2}$, Lars Bärring ${ }^{1}$ \\ ${ }^{1}$ Department of Physical Geography and Ecosystems Analysis, PO Box 118, Lund University, 22100 Lund, Sweden \\ ${ }^{2}$ Malmö University, 20506 Malmö, Sweden \\ *Present address: Climatic Research Unit, University of East Anglia, Norwich NR4 7TJ, United Kingdom
}

\begin{abstract}
Wind erosion causes severe damage on sandy soils in agricultural areas of north-west Europe. The weather conditions during erosion events are the result of the general atmospheric circulation and are key components in the erosion process. Principal component analysis (PCA) in combination with a non-hierarchical cluster analysis was conducted on de-seasonalized daily meansea-level pressure (MSLP) patterns of north-western Europe between 1973 and 1991 to determine the main synoptic types associated with wind erosion on sugar beet fields in Scania, southern Sweden. Cluster analysis of the PCA scores indicated that the observations should be grouped into 14 classes for which average MSLP patterns were computed. To assess the relationship between the patterns and wind erosion, 2 indices were computed. Index of Occurrence (IO) is the ratio between the occurrence of the patterns during days with wind erosion and the occurrence during the entire wind erosion season. Index of Erosion Severity (IES) is computed by weighting the IO with the area damaged by wind erosion associated with each pressure pattern. The IES identifies 2 pressure patterns that have significantly larger values than the other patterns. The most important is a pattern showing easterly flow over Scania, associated with $74 \%$ (912 ha of 1235 ha) of the total damage in the study area. The second most important is a pattern showing westerly flow over Scania, associated with $5 \%$ (63 ha) of the total damage. Both pressure patterns contain strong pressure gradients (in different directions) located over Scania. Depending on the location of the maximum gradient these patterns could be associated with wind erosion in other regions of north-western Europe.
\end{abstract}

KEY WORDS: Scania - Wind erosion - Large-scale circulation - Principal component analysis · Cluster analysis

Resale or republication not permitted without written consent of the publisher

\section{INTRODUCTION}

Extensive agricultural areas on sandy soils in northwest Europe experience severe damage due to wind erosion in terms of reduction of production, pollution and loss of topsoil. According to Oldeman et al. (1991), around 42 million ha of the European Union (EU) area are affected by wind erosion. The largest costs related to wind erosion in cultivated regions in Europe are for crop losses and additional expenses associated with resowing (Riksen \& De Graaff 2001). Thus, damage to high-cost crops such as sugar beet and oilseed rape is particularly expensive for the farmer (Riksen \& De
Graaff 2001). In Sweden, Denmark and The Netherlands the damage on arable land due to wind erosion has long been recognised as a problem that in some cases has led to the development and application of wind erosion protection measures (e.g. Als 1989, Eppink \& Spaan 1989, Hansen 1989, Jönsson 1994).

Scania (in Swedish: Skåne), southern Sweden, is partly levelled and intensively cultivated. This landscape is similar to the larger north European agricultural region, the Quaternary Plains, which extends from Belgium to Poland. This environment is susceptible to wind erosion during dry weather conditions in spring when fields are largely bare. 
The effects of wind erosion in this region were recorded as early as 1749 by Carl von Linnaeus, who travelled through Scania in the late 1740s (Linnaeus 1751). Dunes formed in the sandy soil areas of Scania during the 18th and early 19th centuries suggest that wind erosion was more intensive during this period. Mattsson (1987) described the increase of wind erosion problems during this period as a result of an increase in ecological pressure on the landscape caused by a growing population and a high frequency of strong easterly winds. Descriptions of several recent severe wind erosion events in Scania have been published (Rasmusson 1962, Åhman 1974, Mattsson et al. 1983, Nihlén 1990, Nihlén \& Åhman 1991).

Wind erosion can be conceptualised as 'soil erodibility' and 'wind erosivity'. The term erodibility includes properties of the soil that are relevant for soil particle mobilisation and transport. Erosivity refers to the ability of the wind to erode. Furthermore, the amount of soil moisture and vegetation or crop cover are of critical importance as these factors have inhibiting effects on wind erosion.

Whilst westerly winds dominate in Scania, winds from the easterly sector cause most severe wind erosion (Jönsson 1992). Easterly winds evolve during an anti-cyclonic situation with the high pressure located over Scandinavia and lower pressure located over the European continent. An easterly airflow implies advection of a continental air mass, which is generally drier and thus less associated with precipitation compared to westerly airflow. Westerly airflow is associated with advection of moist air from the North Atlantic that often produces precipitation in connection with fronts and cyclones. As the atmospheric circulation is governed by the pressure distribution, there is a fundamental connection between the sea level pressure distribution and erosive winds.

The ongoing debate regarding climate change has highlighted the importance of understanding relationships between the atmospheric circulation and surface processes, such as wind erosion. However, in order to investigate the impact of climate change on wind erosion in Scania the relationship between atmospheric circulation and wind erosion must first be established. As yet, for Scania and north-west Europe this relationship is not well understood. In this paper we aim to identify and investigate those synoptic pressure distribution patterns that are associated with wind erosion in Scania. At a later stage the results of this work may be used for examining the impact of climate change on wind erosion.

The area for which the mean-sea-level pressure (MSLP) patterns are computed comprises large parts of northern Europe and the North Atlantic. This region is dominated by meteorological features that shape the climate of southern Scandinavia: the Azores High, the Icelandic Low, Polar and Arctic fronts with associated cyclonic activities and the thermal Asian anticyclone developed over the Asian continent in winter. These features are important for the weather development in Scania even though their influence is mainly indirect on the regional winds over southern Sweden.

\section{DATA SETS}

Four data sets are used: a wind erosion indicator (1948-1991); measurements of wind speed and wind direction (1973 onwards); precipitation (1895-1990/ 1958 onwards) and gridded MSLP (1899-1999). The wind data begin in 1973 and the wind erosion indicator is not consistent after 1991. The study period is thus 1973-1991, when all 4 data sets overlap.

\subsection{Indicator of actual wind erosion}

The sugar beet company DANISCO Sugar, formerly the Swedish Sugar Company (Sockerbolaget AB), kept records for each factory district of the areal extent of sugar beet fields that needed re-sowing due to wind erosion during the period 1949-1997. These records are based on weekly reports from the farmers and cover a period each year when the crop is vulnerable to external damage. More specifically, the wind erosion indicator data begin each year when $50 \%$ of the total sugar beet hectareage is sown and end when the crop cover is sufficiently protective (Jönsson 1992). We use these data as an indicator for the occurrence of actual wind erosion. For the purpose of this study we refer to weeks when re-sowing was needed as 'erosion weeks'. The factory district used in this study is Jordberga, situated in southeast Scania (Fig. 1). Over time, the numbers of districts and their areal extent have changed because sugar beet factories have closed and the districts were agglomerated; amongst those affected was Jordberga. However, these changes are accounted for in the record of wind erosion events 1973-1988 (Jönsson 1992). From 1988 no alterations regarding the extent of the district were made until 1992 when the Jordberga district was merged with another district, which is located some $300 \mathrm{~km}$ NE of Jordberga. After this agglomeration of districts there were no means to separate the wind erosion data belonging to each district and thus data after 1991 were omitted from the analysis.

During the period 1973-1991, wind erosion was reported in 36 weeks for the Jordberga district. These erosion weeks occurred mainly during the second half of May and to a lesser extent during the first halves of 


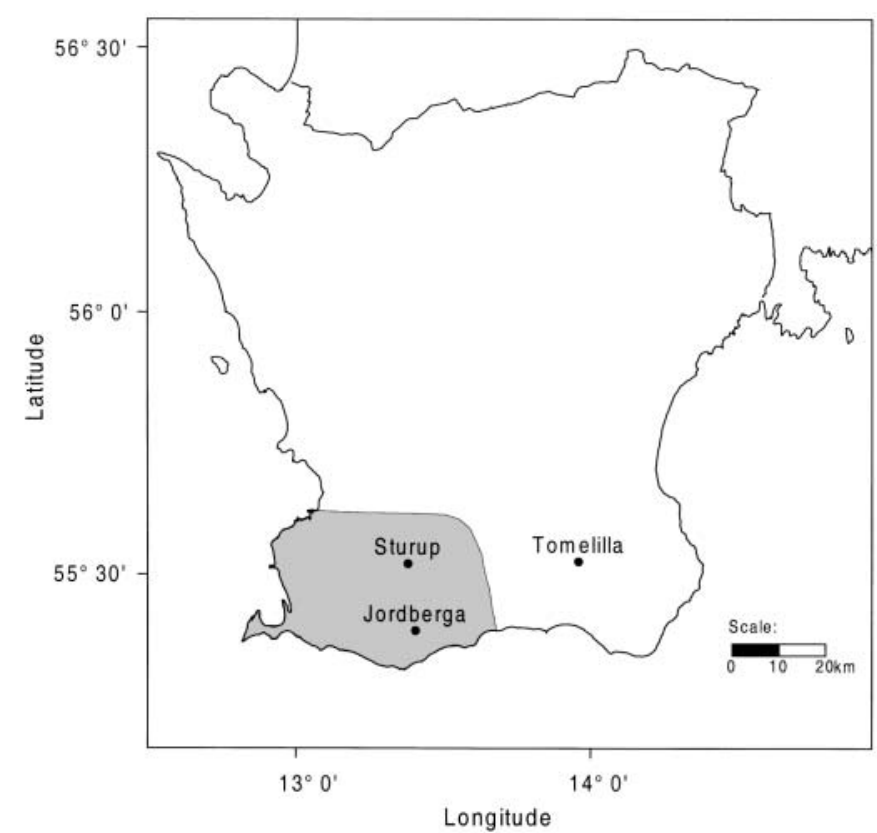

Fig. 1. Map showing the sugar beet district of Jordberga (the shaded area) and the locations of the Sturup, Jordberga and Tomelilla SMHI meteorological stations in Scania. See Fig. 2 for the location of Scania

May and June, and also on one occasion in early July. The extent and timing of wind erosion varies from year to year depending on weather conditions but is generally restricted to April 15-July 15, taking into account the single observation in early July. From here on we refer to the period April 15-July 15 as the 'wind erosion season'.

Wind speed (Section 2.2) and precipitation data (Section 2.3) were used to identify days within the erosion weeks that are most likely to experience wind erosion. These days are defined as 'erosion days'.

\subsection{Wind data}

Wind erosion indicator data are available only on a weekly basis. It is, however, necessary to identify the days within each week when wind erosion is most likely to occur. For that purpose we use wind speed measurements from the Swedish Meteorological and Hydrological Institute (SMHI) weather station at Sturup Airport (Fig. 1). This station is located within the study area.

Wind speed $\left(\mathrm{m} \mathrm{s}^{-1}\right)$ and direction (10 degree bins) are measured simultaneously at two $10 \mathrm{~m}$ masts located at each end of the main runway of the airport. The masts are approximately $2 \mathrm{~km}$ apart in the north-south direction. Only the recording from the mast with the larger of the two 10 min averages of wind speed is retained in the data set. The observation times were every third hour (00:00, 03:00, 06:00, ..., 21:00 h UTC [universal time coordinated]) during the time period January 1, 1973-November 6, 1988 and twice every hour (00:00 and 00:30 h, etc.) from November 7, 1988 onwards. To ensure that the data set is consistent we used a 3 hourly resolution throughout the entire study period (1973-1991).

A wind speed threshold was used to identify days with potential wind erosion within the erosion weeks. If this threshold was exceeded at any of the 8 wind observations during a day, it was kept for the next stage when precipitation was considered. We wanted to use a threshold that gave a substantial reduction in the number of erosion days without rejecting any week with substantial wind erosion, as it is likely that during the erosion week wind erosion only occurred on a few days. We tested several thresholds, ranging from 6 to $12 \mathrm{~m} \mathrm{~s}^{-1}$ in steps of $1 \mathrm{~m} \mathrm{~s}^{-1}$, and arrived at $9 \mathrm{~m} \mathrm{~s}^{-1}$ as a suitable wind speed threshold. This threshold reduced the data set from 252 possible erosion days to 87 . Only 3 erosion weeks (in 1974, 1989 and 1990) with minor wind erosion were rejected. Lower thresholds gave smaller reductions and larger thresholds rejected 5 or more of the 36 erosion weeks.

\subsection{Precipitation data}

Precipitation is generally an inhibiting factor on wind erosion because the soil surface erodibility is substantially lower when it is wet. Thus, it is important to take into consideration the precipitation for each possible erosion day identified using the wind speed threshold. Here we use daily precipitation data $(\mathrm{mm})$ from the SMHI station Jordberga (1895-1990) located within the study area (Fig. 1) for the period 1973-1990. The station was closed in 1991. Five missing months (April 1975, July 1979, February and May 1989 and March 1990) and the whole missing year 1991 were replaced using data from the nearby SMHI station Tomelilla (1958 onwards) (Fig. 1). When using a threshold of more than $3 \mathrm{~mm}$ precipitation the number of erosion days decreased from 87 to $75 \mathrm{~d}$. Further lowering of the threshold required omitting one of the erosion weeks in 1984, which was not desirable.

\subsection{Pressure data}

Daily (12:00 h UTC) gridded ( $5^{\circ}$ latitude by $5^{\circ}$ longitude) MSLP data from the National Center for Atmospheric Research (NCAR data set DS010.0) for the period 1973-1999 was used for the map pattern classification. The grid window covered the area $17.5^{\circ} \mathrm{W}$ to $32.5^{\circ} \mathrm{E}$ and 42.5 to $77.5^{\circ} \mathrm{N}$ and included in total 70 grid 


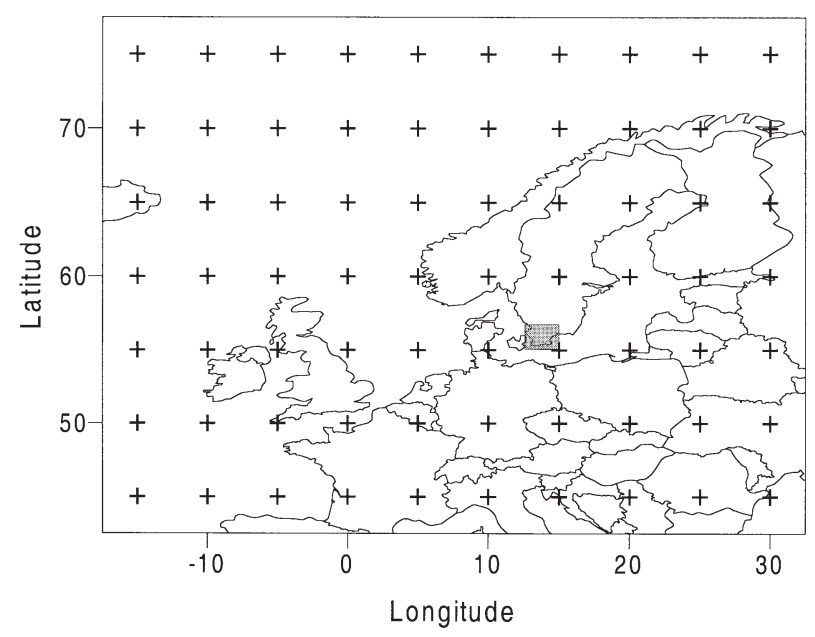

Fig. 2. Grid points from the National Center for Atmospheric Research (NCAR) data set used in the principal component analysis (PCA). The grey square marks roughly the region of Scania (Fig. 1)

cells (Fig. 2). During the study period (1973-1991) the data set originates from the US Navy operational objective analysis scheme. Missing data grids comprised $140 \mathrm{~d}(1.5 \%)$ and were replaced by linear interpolation between adjacent values in each grid cell time series.

\section{METHODOLOGY}

\subsection{Map-pattern classification}

There are several methods to extract the essential modes of variation in a gridded data set, such as a MSLP grid, into a finite number of patterns. These methods are usually described as either subjective or objective, or more appropriately as manual or automated (Yarnal 1993). Examples of the former are the well-known Lamb weather type classification (Lamb 1950) and the European Grosswetterlagen (Hess \& Brezowsky 1977). Examples of automated classification methods include correlation-based or eigenvectorbased methods such as principal component analysis (PCA). Advantages and disadvantages of using the different approaches are discussed by, e.g., Yarnal (1993) and Frakes \& Yarnal (1997). The main advantage of using an automated classification is its repeatability and time efficiency.

Here, we use PCA conducted in the spatial domain followed by a cluster analysis of the PCA scores to extract and group the underlying structure of variation in the spatial pressure pattern. Averaging these pressure patterns within each cluster produces a set of patterns that describes the typical synoptic pressure patterns for the study area. Together these patterns comprise a map-pattern catalogue for Scania.

Although the PCA technique includes a number of semi-subjective decisions, such as method for component rotation, number of principal components (PCs) to retain for further analysis, etc., the method is intensively used and is a well-established method for analysis of spatial variation in several climatological variables such as MSLP (e.g. White et al. 1991, Kidson 1994, Compagnucci \& Salles 1997).

\subsection{Pressure data filtering}

Analysis of the pressure patterns used data from the entire year in order to include the full range of spatial variability in the pressure over northern Europe. However, to avoid the result of the PCA being swamped by seasonal characteristics, the pressure data must first be de-seasonalized (Yarnal 1993). High-pass filtering with a centred moving average filter was used to remove all common variance on a time scale longer than the maximum duration of synoptic systems (Hewitson \& Crane 1992). The filter length used was slightly smaller than the first significant harmonic of the data set. Hewitson \& Crane (1992) estimated the first harmonic using the auto-correlation function and power spectra of the pressure time series. We used SPECTRUM software (Schultz \& Stattegger 1997) to estimate the significant harmonic. The harmonic analysis of all 70 grid cell time series gave a significant (at $\alpha=0.05$ ) period at $16 \mathrm{~d}$ in $61 \%$ of the time series. The length of the moving average filter was thus set to $15 \mathrm{~d}$. Centred on the day concerned, the filter was applied on daily map averages (the filter process implies that the first and last $7 \mathrm{~d}$ are removed from the MSLP grid time series). Finally, the pressure grid was re-calculated as the deviations between each grid cell and the moving average, thus keeping the spatial pattern within each daily pressure map. All analyses were based on the high-pass filtered pressure data.

\subsection{Identification of synoptic pressure patterns}

\subsubsection{Principal component analysis}

PCA extracts dominant patterns of variability from statistical fields, such as maps of pressure distribution (von Storch \& Zwiers 1999). Here grid cells with similar temporal variation were grouped using S-mode PCA (Yarnal 1993). The S-mode refers to the decomposition of the input de-seasonalized pressure matrix, where rows represent time and columns grid cells. A correlation matrix was developed on the input data matrix, 
Table 1. Summary of the principal component analysis (PCA)

\begin{tabular}{|lccc|}
\hline PC & Eigenvalue & $\begin{array}{r}\text { Explained } \\
\text { variance }(\%)\end{array}$ & $\begin{array}{c}\text { Cumulative explained } \\
\text { variance }(\%)\end{array}$ \\
\hline 1 & 22.7 & 32 & 32 \\
2 & 15.5 & 22 & 55 \\
3 & 11.6 & 17 & 71 \\
4 & 5.8 & 8 & 79 \\
5 & 4.6 & 7 & 86 \\
6 & 2.2 & 3 & 89 \\
7 & 1.5 & 2 & 91 \\
8 & 1.3 & 2 & 93 \\
9 & 0.8 & 1 & 94 \\
10 & 0.6 & 1 & 95 \\
\hline
\end{tabular}

which comprised 9117 observations of MSLP on 70 grid nodes. Richman (1986) suggested rotation of the PCs to avoid domain shape dependence, sub-domain instability, sampling problems and inaccurate representation of the underlying physical relationships. There are 2 basic techniques that may be used for rotation: orthogonal rotation and oblique rotation. The former method changes the relationship between the components but retains the orthogonal constraint of the eigenvector model. Oblique rotation patterns may become more distinct by allowing correlated PCs, but this prohibits the calculation of explained variance, which is a useful measure of each component's importance. In the next stage of the analysis the PC scores are clustered and average pressure maps are produced for each cluster; hence, the fine-tuning provided by the oblique rotation is unnecessary and may even complicate the clustering process (Yarnal 1993). Here the widely applied Varimax rotation (Kaiser 1958) is used for rotating the PCs in order to obtain more easily interpretable loading patterns. See Richman (1986) and von Storch \& Zwiers (1999) for further details on the Varimax rotation.

Six PCs accounted for $89 \%$ of the total variance (Table 1), which together described the essential synoptic patterns over the study area. The decision to retain 6 PCs for the cluster analysis was based on 2 graphical aids: the scree plot (Cattell 1966, Fig. 3a) and the log scree plot (Davis \& Kalkstein 1990, Fig. 3c), and Kendall-North's rule-of-thumb (North et al. 1982, Fig. 3b). The scree plot (Fig. 3a) levels out at PC 6, and the largest value in Fig. 3c refers to the distance between PC 5 and PC 6. These graphs indicate a rapid decrease in explained variance between PC 5 and PC 6, after which little is added to the explained variance. The distance between the neighbouring eigenvalues and the sampling error of the eigenvalue reach the same magnitude at about PC 7 (Fig. 3b); thus, there should be no contamination between PC 1 and PC 6.
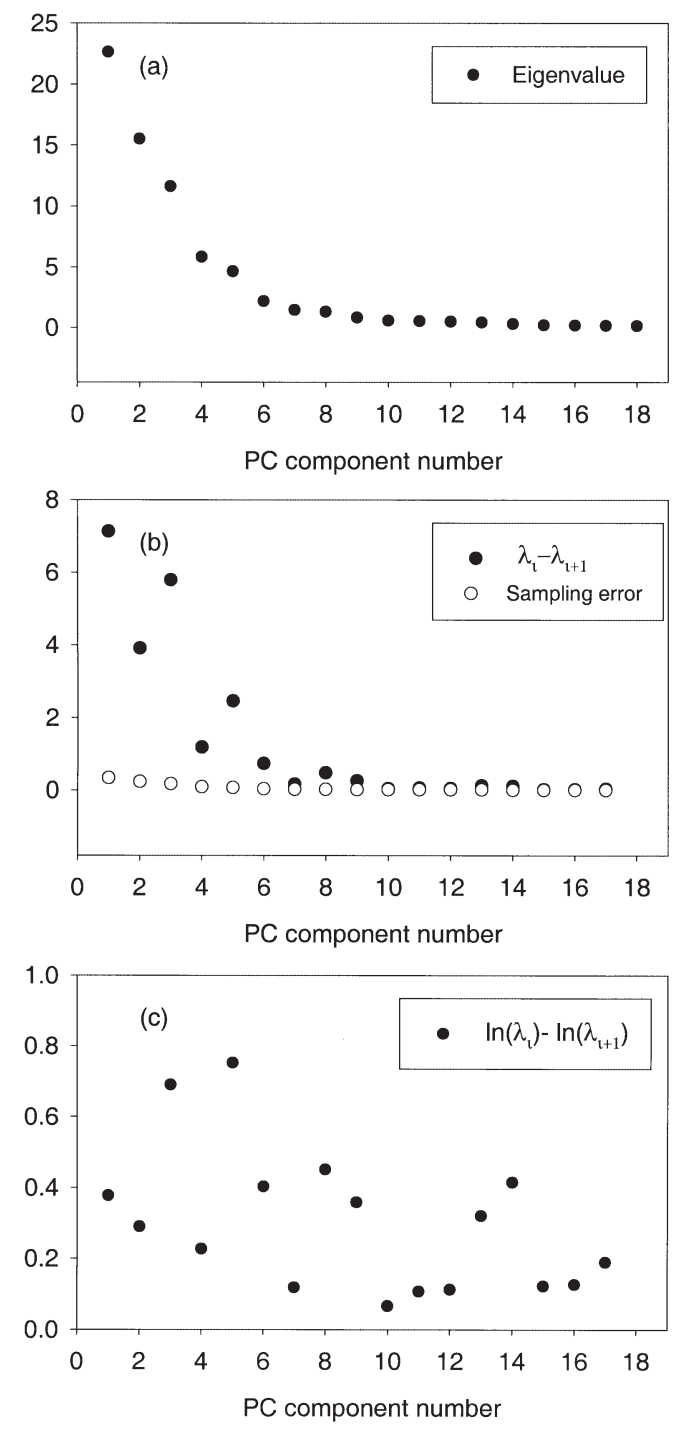

Fig. 3. Scree plot of the PCA of the daily mean-sea-level pressure (MSLP) grids. (a) Eigenvalues, (b) component-tocomponent change in eigenvalues $\left(\lambda_{i} \bullet\right)$ and their respective sampling error $(\mathrm{O})$, (c) component-to-component change in the natural logarithm of the eigenvalues plotted against the component number

Maps of rotated PC loadings (RPCs) are shown in Fig. 4. RPC 1 shows a high pressure centre located over central Europe that may be a part of the northerly ridge that during winter stretches from the Azores high to the Asian high over Spain, central Europe to Russia (Fig. 4a). RPC 2 shows high pressure near Iceland that extends across the North Sea and southern Scandinavia to another high pressure area over south-eastern Europe (Fig. 4b). RPC 3 displays an extensive deep low pressure cell centred between Norway and the British Isles and that dominates large parts of Europe (Fig. 4c). RPC 4 (Fig. 4d) shows a trough in a south-west to 

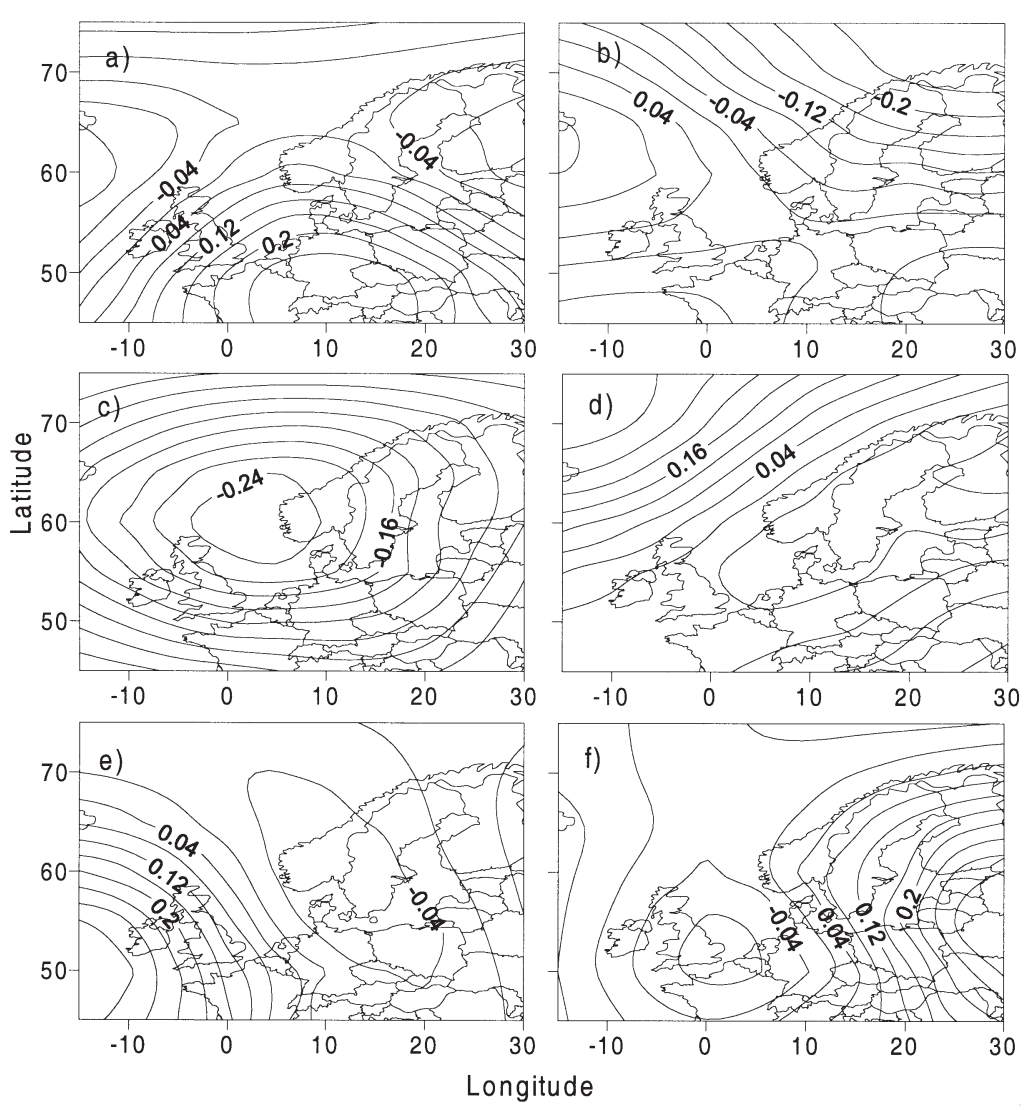

Fig. 4. (a-f) Loading patterns of the first 6 PCs of the daily de-seasonalized MSLP grids mises a chosen criterion (Everitt 1986). Starting from an initial classification, days were transferred from one group to another or swapped with days from other groups until no further improvement occurred in the criterion value. The within-class dispersion measure, giving compact groups, was chosen as the clustering criterion (Everitt 1986).

The cluster analysis was run between 1 and 20 clusters. The number of clusters chosen was based on the distribution of erosion days within the different clusters. The largest number of erosion days was assembled into 1 cluster when 14 clusters were used in the cluster analysis. For larger or smaller number of clusters the erosion days were spread out in a less distinct way. Thus, the final number of clusters was set to 14 even though the purely statistical criterion indicated that 11 clusters were enough. Hereafter we will refer to the clusters as patterns P1 to P14.

\subsubsection{Identification of patterns associated with erosion}

To identify those patterns that are generally more frequent during the erosion days compared to the erosion season, a simple Index of Occurrence (IO) was created: north-east direction over Scandinavia and RPC 5 (Fig. 4e) shows a pronounced high west of the British Isles and a low over southern Scandinavia. RPC 6 (Fig. 4f) shows a distinct high pressure over Eastern Europe and a low pressure over the British Isles.

Our 3 leading modes show high similarity to the 3 leading patterns of an Empirical Orthogonal Analysis (EOF) performed on monthly European pressure series by Slonosky et al. (2000). Whilst they chose to use only those 3 modes, we included an additional 3 modes. The larger number needed to represent the variation may be explained by larger variation in a daily data set compared to a monthly data set.

\subsubsection{Clustering of PC scores}

To find days with similar characteristics regarding their similarity to the PC loadings, the PC scores were grouped using a cluster analysis. Since there was no reason to assume an underlying hierarchical structure in the data we used a non-hierarchical cluster analysis, which partitioned the days into a pre-determined number of groups, using an iterative algorithm that opti-
$\mathrm{IO}=\frac{\text { Relative frequency during the erosion days }}{\text { Relative frequency during the erosion season }}$

By weighting the IO with the total re-sown area, we defined an Index of Erosion Severity (IES) that identified those patterns that were associated with large wind erosion damage and that were fairly common during erosion days relative to the erosion season.

$$
\mathrm{IES}=\mathrm{IO} \times \text { total re-sown area (ha) }
$$

Pressure patterns with substantially higher IES values were defined as 'erosive patterns' (see Section 4.2).

\section{RESULTS}

\subsection{Typical climate features of wind erosion events}

The wind conditions during the erosion season (April 15-July 15), the erosion days and days with severe wind erosion (events with re-sown hectareage exceeding the 75 th percentile, 10 ha) are displayed in Fig. 5. For the study period (1973-1991) the wind direction during the erosion season was characterised 

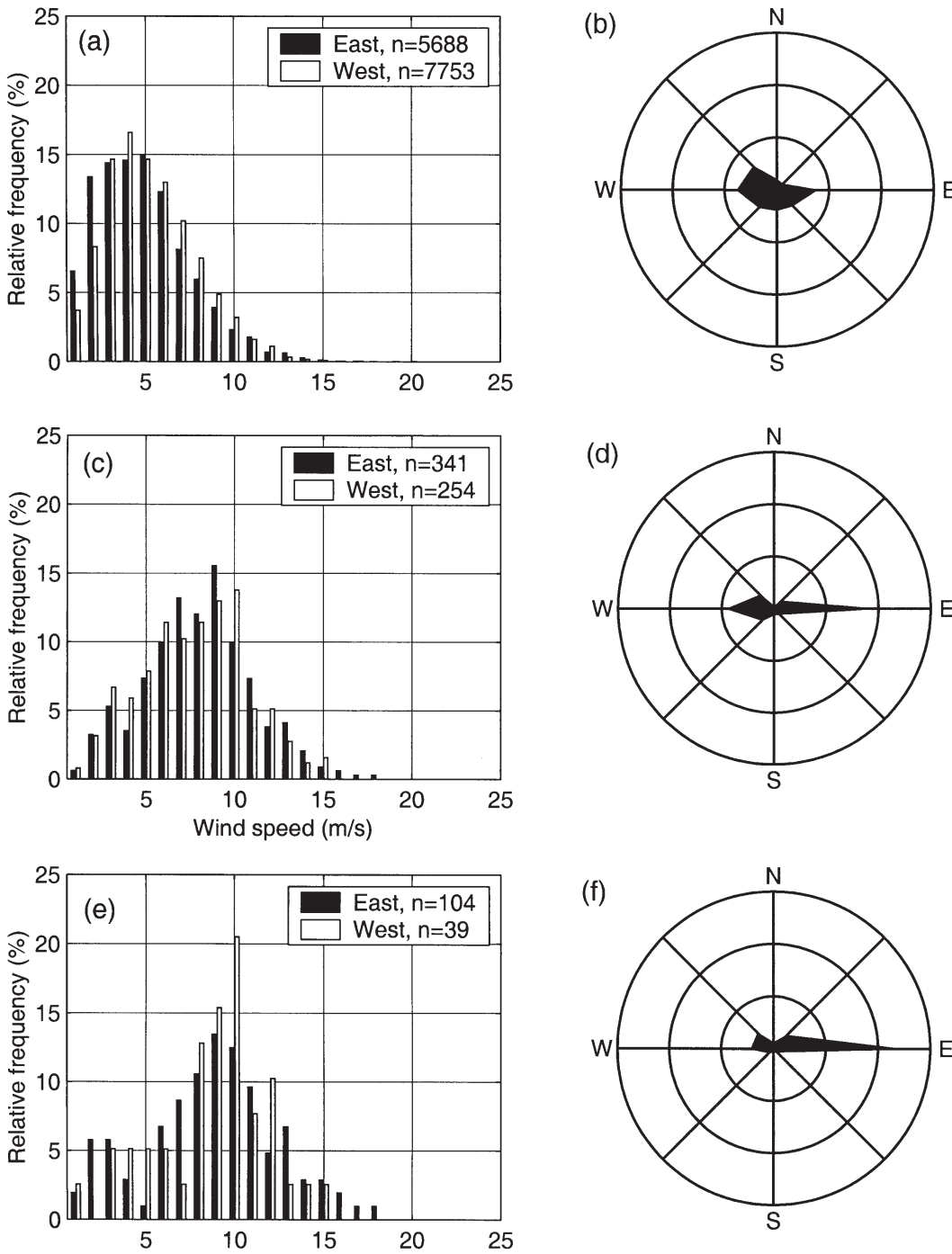

Fig. 5. (a to f) Wind climate (1973 to 1991) at the Sturup SYNOP station (including all 8 observations per day). Wind speed $\left(\mathrm{m} \mathrm{s}^{-1}\right)$ and wind direction distribution (on 8 sectors) for $(a, b)$ the erosion season (April 15 to July 15), $(c, d)$ erosion days. (e,f) erosion days associated with re-sown area $>10$ ha (the $75 \%$ percentile). The inner circle marks $25 \%$, the middle circle $50 \%$ and the outer circle $75 \%$

by a bimodal distribution (east $42 \%$ and west $58 \%$ ) and a wind speed distribution, which had a peak at 4 to $5 \mathrm{~m} \mathrm{~s}^{-1}$. The high wind speeds were usually associated with westerly winds (Fig. 5a,b). The wind conditions differed markedly from the average conditions during the erosion days. During the erosion days, easterly winds dominated $(57 \%)$ and the distribution of wind speeds was clearly shifted towards higher wind speeds, both for easterly and westerly winds (Fig. $5 \mathrm{c}, \mathrm{d})$. Days with severe wind erosion had an even larger proportion of easterly winds (73\%; Fig. 5f) and displayed the highest wind speeds (Fig. 5e).

The synoptic circulation during wind erosion events is shown in Fig. 6. As the previous analysis (Fig. 5) clearly revealed a bi-modal (east/west) distribution of wind directions during wind erosion days, the erosion days were separated into a westerly (181 to $360^{\circ} \mathrm{W}$, $33 \mathrm{~d}$ ) and an easterly (1 to $180^{\circ} \mathrm{E}, 42 \mathrm{~d}$ ) group. The average de-seasonalized pressure maps for each group (Fig. 6a,b) display strong pressure gradients over southern Sweden. For the easterly situations (Fig. 6a), the gradient is between high pressure over mid-Scandinavia and low pressure over central Europe. The small standard deviations over Scandinavia (Fig. 6c) indicate that the anticyclone is a persistent feature. The westerly situations (Fig. 6b) show a low over the Bay of Bothnia and a ridge extending over the North Atlantic towards central Europe. The combination of the high pressure to the southwest and the larger standard deviations over Scandinavia suggests that the cyclones follow a northerly track over Scandinavia (Fig. 6d).

\subsection{Relationships between pressure patterns and wind erosion}

Table 2 shows the frequency of each pattern during the entire year, the erosion season, the erosion weeks, the erosion days, the easterly erosion days and the westerly erosion days. The group of easterly erosion days is somewhat larger compared to the group of westerly erosion days. The most frequent patterns during the year are P1 (11\%) and P14 $(12 \%)$. During the erosion season, these patterns are relatively even more frequent and together with P2, P5 and P7 make up $72 \%$ of the total number of days. During erosion weeks, and particularly on the erosion days, P7 is the most dominant pattern, occurring on ca. $30 \%$ of the erosion days and $55 \%$ of the easterly erosion days. Hence, the most common pattern during erosion days is associated with easterly winds in Sturup.

Pressure patterns P5, P7, P9, P12 and P13 all have an IO $>1$, which implies that they are more common on erosion days than during the erosion season in general (Table 2). Large IO values may occur both when the frequency is rather high during the erosion season (but even higher during erosion days), e.g. P7, and by being rare during the erosion season (but being relatively frequent on the erosion days), e.g. P9. 
The areal extent of the wind erosion damage associated with each pattern is shown in Table 3, together with the number of days with slight/moderate/severe erosion and the total re-sown area for each pressure pattern. The severity grouping of the different erosion days was based on the 25th and 75th percentiles (1 and 10 ha respectively) of the re-sown areas of the erosion days. The definitions of the groups are: slight wind erosion ( $<1 \mathrm{ha}$ ), moderate wind erosion (1 to $10 \mathrm{ha}$ ) and severe wind erosion (>10 ha).
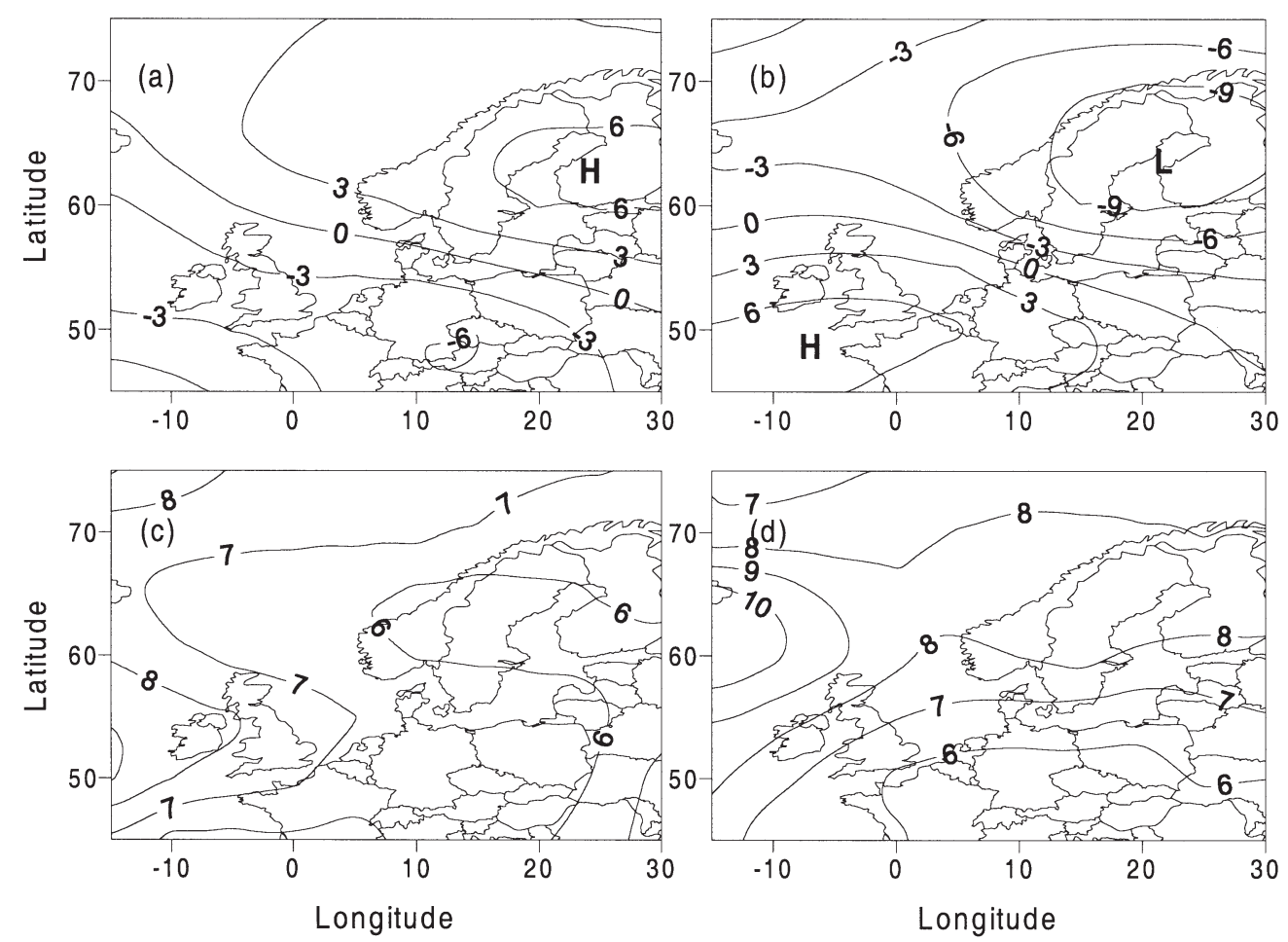

Fig. 6. Maps of averaged de-seasonalized pressure (hPa) for the identified erosion days with (a) easterly and (b) westerly winds and their corresponding standard deviations (c) and (d)

Table 2. Relative frequency (\%) of each pressure pattern (P) during the entire year, the erosion season, the erosion weeks and the erosion days in Jordberga, south-east Scania, southern Sweden. Number of erosion days within each pattern with easterly (1 to $180^{\circ} \mathrm{E}$ ) and westerly winds $\left(181\right.$ to $360^{\circ} \mathrm{W}$ ) respectively. The Index of Occurrence (IO) is the relative importance of each pattern during the erosion days relative to the erosion season. The italic digits in the first row denote the sum $(N)$ of observations per column. All the IOs that exceed unity are indicated in bold

\begin{tabular}{|c|c|c|c|c|c|c|c|}
\hline Pattern & $\begin{array}{l}\text { Year } \\
(\%)\end{array}$ & $\begin{array}{c}\text { Erosion season } \\
(\%)\end{array}$ & $\begin{array}{c}\text { Erosion week } \\
(\%)\end{array}$ & $\begin{array}{c}\text { Erosion day } \\
(\%)\end{array}$ & $\begin{array}{c}\text { Erosion days } \\
\text { East }\end{array}$ & $\begin{array}{c}\text { Erosion days } \\
\text { West }\end{array}$ & IO \\
\hline$N$ & 6932 & 1748 & 253 & 75 & 42 & 33 & \\
\hline P1 & 11 & 18 & 16 & 8 & 2 & 4 & 0.4 \\
\hline P2 & 8 & 9 & 5 & 4 & 3 & 0 & 0.4 \\
\hline P3 & 6 & 4 & 7 & 4 & 3 & 0 & 1.0 \\
\hline $\mathrm{P} 4$ & 8 & 7 & 9 & 3 & 1 & 1 & 0.4 \\
\hline P5 & 9 & 10 & 8 & 13 & 1 & 9 & 1.3 \\
\hline P6 & 8 & 5 & 2 & 3 & 0 & 2 & 0.5 \\
\hline P7 & 8 & 14 & 21 & 33 & 23 & 2 & 2.3 \\
\hline P8 & 5 & 0 & 0 & 0 & 0 & 0 & 0 \\
\hline P9 & 4 & 1 & 2 & 7 & 0 & 5 & 7.4 \\
\hline 10 & 6 & 0 & 0 & 0 & 0 & 0 & 0 \\
\hline P11 & 4 & 0 & 0 & 0 & 0 & 0 & 0 \\
\hline P12 & 7 & 3 & 4 & 4 & 0 & 3 & 1.5 \\
\hline P13 & 6 & 6 & 9 & 8 & 3 & 3 & 1.4 \\
\hline P14 & 12 & 21 & 18 & 13 & 6 & 4 & 0.6 \\
\hline
\end{tabular}


The relative damage, computed as the percentage of the total re-sown area, associated with each pattern shows that the greatest damage is associated with $\mathrm{P} 7$ (74\%), followed by P14 (6\%), P9 (5\%), P5 (4\%), P1 (4\%) and P3 (3\%) (Table 3). Remaining patterns are associated with minor damage. Each erosion day was given a proportion of the weekly re-sown area relative to the number of erosion days within the erosion week (e.g. $1 / 3$ if there are 3 erosion days within the erosion week under consideration).

A plot of IES versus pressure pattern is shown in Fig. 7. By visual inspection, we observe that the pres-

Table 3. For each pattern, number of days with slight erosion (less than the 25th percentile, 0 to $1 \mathrm{ha}$ ), moderate erosion (1 to $10 \mathrm{ha}$ ), severe erosion (above the 75th percentile, $>10 \mathrm{ha}$ ), the total re-sown hectareage (ha) and the relative damage expressed as the percentage of the total re-sown area associated with each pattern are shown

\begin{tabular}{|lcrrrr|}
\hline Pattern & $\begin{array}{c}\text { Slight } \\
\text { erosion }\end{array}$ & $\begin{array}{c}\text { Moderate } \\
\text { erosion }\end{array}$ & $\begin{array}{c}\text { Severe } \\
\text { erosion }\end{array}$ & $\begin{array}{c}\text { Re-sown } \\
\text { area } \\
\text { (ha) }\end{array}$ & $\begin{array}{c}\text { Relative } \\
\text { damage } \\
(\%)\end{array}$ \\
\hline P1 & 2 & 2 & 2 & 50 & 4 \\
P2 & 2 & 1 & 0 & 3 & 0 \\
P3 & 1 & 0 & 2 & 43 & 3 \\
P4 & 2 & 0 & 0 & 1 & 0 \\
P5 & 2 & 7 & 1 & 53 & 4 \\
P6 & 1 & 1 & 0 & 3 & 0 \\
P7 & 3 & 14 & 8 & 912 & 74 \\
P8 & 0 & 0 & 0 & 0 & 0 \\
P9 & 0 & 3 & 2 & 63 & 5 \\
P10 & 0 & 0 & 0 & 0 & 0 \\
P11 & 0 & 0 & 0 & 0 & 0 \\
P12 & 0 & 3 & 0 & 17 & 1 \\
P13 & 3 & 3 & 0 & 11 & 1 \\
P14 & 3 & 4 & 3 & 79 & 6 \\
\hline
\end{tabular}

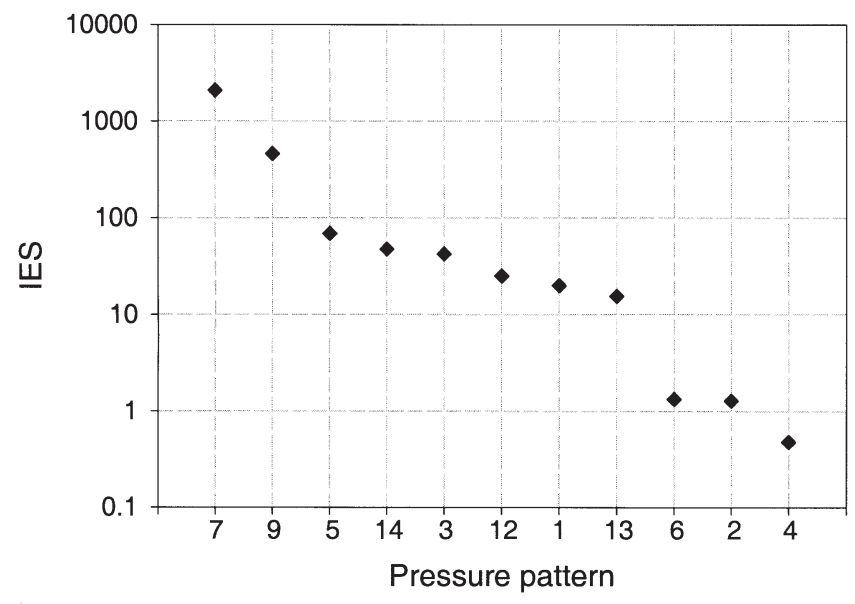

Fig. 7. Index of Erosion Severity (IES) for each pressure pattern. The IES values are plotted in descending order sure patterns can be separated into 3 groups: the easterly P7 and the westerly P9 associated with highest IES (460 to 2100); P5, P14, P3, P12, P1 and P13 (IES = 15 to 70 ) and the remaining patterns (IES < 2). P9 is very infrequent during the erosion season but is associated with large damage (re-sown area), whereas P7 is frequent during the erosion season and associated with a large number of moderate and severe erosion days (Tables $2 \& 3$ ). Following these 2 patterns is the second group, which is associated with smaller IES values and has several different combinations of IO and IES. Hence, the patterns of the first 2 groups are referred to as the erosive patterns. The discussion in Section 5 will focus on the properties of the erosive patterns, as they are considered to be of primary interest regarding wind erosion in Jordberga.

\subsection{Properties of the erosive patterns}

\subsubsection{Spatial and temporal characteristics}

Fig. 8 shows the average de-seasonalized pressure for each pressure pattern associated with erosion sorted in decreasing order according to their IES. Since the maps are based on all days during the entire year they show smooth patterns. The highest IES is obtained by P7, which shows a low pressure system over central Europe with an easterly flow over Scania (Fig. 8a). The pressure pattern of P7 shows obvious similarities to that of the easterly erosion days shown in Fig. 6a. For P9, a strong north-westerly flow over Scania due to a pronounced pressure gradient between low pressure in the northern parts of Scandinavia and high pressure over western France is observed (Fig. 8b). In the pressure pattern for P5 (Fig. 8c) the dominating feature is low pressure situated over central Norway and Sweden, producing a westerly to north-westerly flow over Scania. P5 was the most frequent pattern amongst the westerly erosion days (Table 2). Together with the pressure pattern of P9, the P5 pressure pattern has a large influence on the average pressure pattern for the westerly erosion days (Fig. 6b). The pressure pattern of P14 (Fig. 8d) displays a saddle-point over southern Scandinavia, with low pressure in the east and west producing a weak largescale pressure gradient over southern Scandinavia. In the averaging process the somewhat different disposition of the pressure centres creates a pattern with weak pressure gradients. Visual inspection of synoptic pressure maps for the days classed as P14 showed the presence of weather systems, such as fronts and low pressure systems, which during a limited time period give high wind speeds in Jordberga. One example of such an event is shown in Fig. 9. Deep low pressure off 

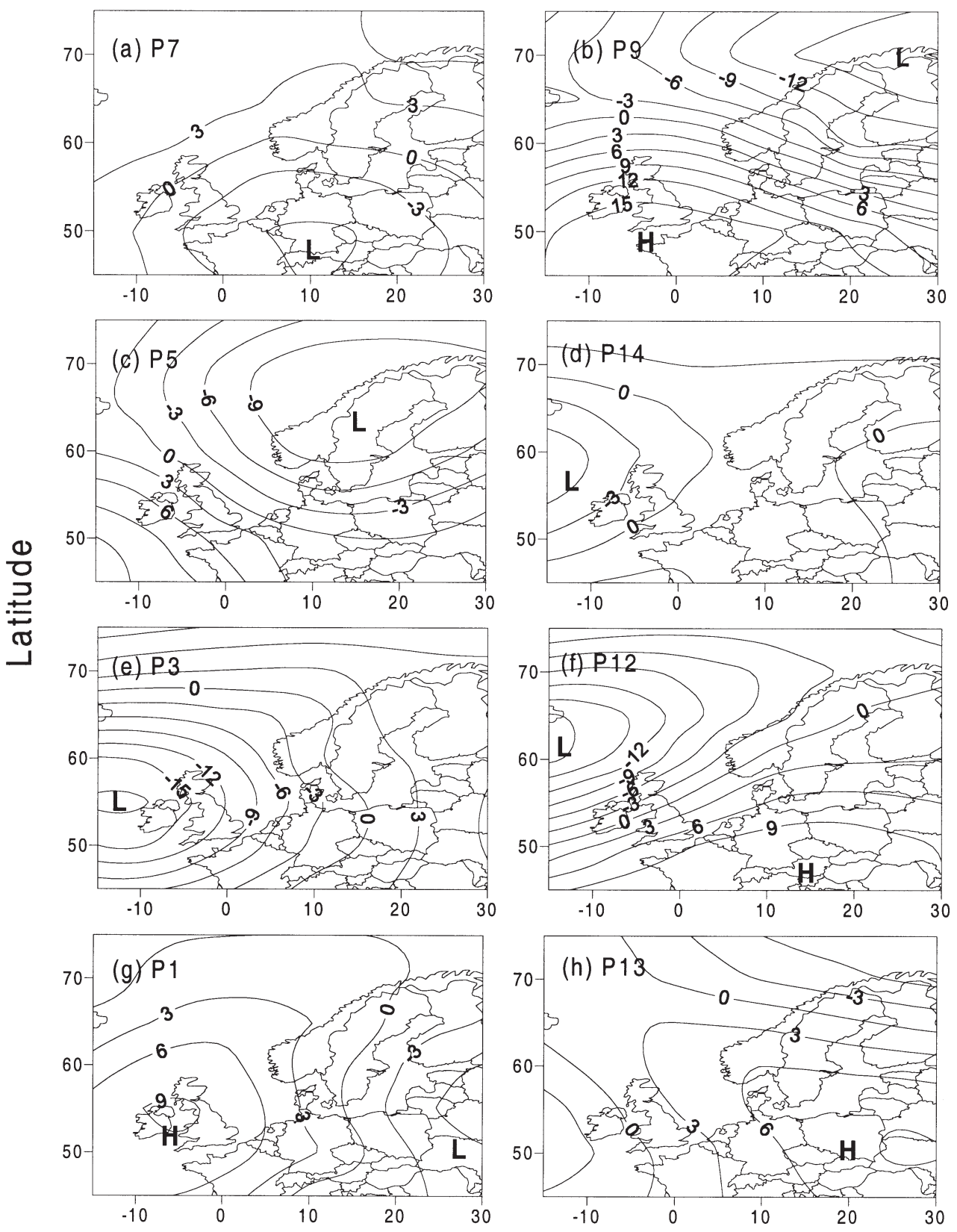

Longitude

Fig. 8. Maps of average de-seasonalized pressure $(\mathrm{hPa})$ for each erosive pattern ordered according to descending values of their respective IES: P7, P9, P5, P14, P3, P12, P1 and P13

the west coast of Ireland dominates the pressure distribution of P3 (Fig. 8e). It produces south-westerly winds over western central Europe that turn southerly/southeasterly over Scandinavia. P12 (Fig. 8f) displays a low pressure system close to Iceland that produces mainly westerly winds over northern Europe (Fig. 8f). The pressure pattern for P1 shows high pressure over the British Isles and low pressure over Russia (Fig. 8g), resulting in a northerly flow over Scania. P13 displays a ridge over Eastern Europe extending towards the southern parts of Scandinavia with associated southeasterly winds (Fig. 8h).

The specific synoptic conditions during the erosion days were investigated using the daily synoptic weather maps from SMHI and Berliner Wetterkarte. These maps were compared with the average pressure patterns in Fig. 8. The comparison showed that the distinctive features of each classified pattern are found in the individ- 
ual weather maps of the erosion days. However, the circulation, as described by the average pressure patterns (Fig. 8), may be different due to the presence of local low or high pressure centres in the region. This suggests that the pressure patterns in Fig. 8 show the average situation, but that conditions during a particular erosion day may contain local variation.

The evolution and persistence of the pressure patterns during the wind erosion season were investigated by counting the pressure patterns of each type that succeeded each of the erosive patterns (Table 4). With the exception of P9, the most common succeeding day's pattern is always classified as the same as that of the day under consideration (ranging from $42 \%$ for P12 to $62 \%$ for P7 and P14). P9 is most often followed by P1 (33\%). The sequences of erosive pressure patterns $3 \mathrm{~d}$ before and after all recorded erosion days are listed in Appendix 1.

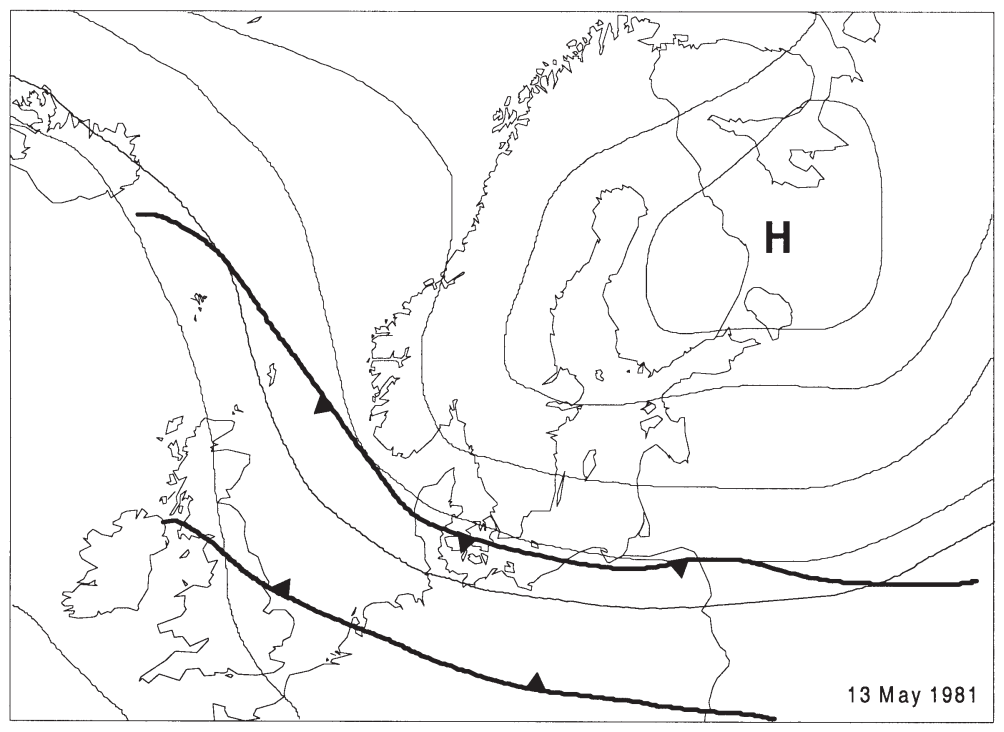

Fig. 9. Synoptic MSLP map (May 13, 1981) re-drawn from the Bodenwetterkarte for 07:00 h MET (Middle European Time; UTC + 0100), Berliner Wetterkarte, Insitut für Meteorologie, Freie Universität Berlin, Berlin. The pattern is classified as P14

From this list it is clear that P7 is the most persistent pattern and that P9 is the most transient pattern.

\subsubsection{Wind characteristics for the erosive patterns}

The large-scale wind characteristics of the erosive patterns as interpreted from the isolines in Fig. 8 were compared with wind observations from the Sturup station. Table 5 shows, for each pattern, the average wind speed and relative frequency of wind direction (8 compass directions). There is a good relationship between the observed wind speed averages and directions of the large-scale atmospheric motion as derived from the patterns. Easterly winds dominate for P7, P3 and P13, westerly winds dominate for P1, P5, P9 and P12,

Table 4. For each erosive pattern, the relative frequency distribution of pressure patterns for the following day is shown. $N$ is the number of observations for each pattern. The table refers to the erosion season

\begin{tabular}{|c|c|c|c|c|c|c|c|c|c|c|c|c|c|c|c|}
\hline Pattern & $\begin{array}{l}\text { P1 } \\
(\%)\end{array}$ & $\begin{array}{c}\text { P2 } \\
(\%)\end{array}$ & $\begin{array}{c}\text { P3 } \\
(\%)\end{array}$ & $\begin{array}{c}\mathrm{P} 4 \\
(\%)\end{array}$ & $\begin{array}{l}\text { P5 } \\
(\%)\end{array}$ & $\begin{array}{c}\mathrm{P6} \\
(\%)\end{array}$ & $\begin{array}{l}\text { P7 } \\
(\%)\end{array}$ & $\begin{array}{c}\text { P8 } \\
(\%)\end{array}$ & $\begin{array}{c}\text { P9 } \\
(\%)\end{array}$ & $\begin{array}{l}\text { P10 } \\
(\%)\end{array}$ & $\begin{array}{l}\text { P11 } \\
(\%)\end{array}$ & $\begin{array}{l}\text { P12 } \\
(\%)\end{array}$ & $\begin{array}{l}\text { P13 } \\
(\%)\end{array}$ & $\begin{array}{l}\text { P14 } \\
(\%)\end{array}$ & $N$ \\
\hline P1 & 57 & 11 & 0 & 6 & 6 & 0 & 7 & 0 & 0 & 0 & 0 & 0 & 4 & 11 & 303 \\
\hline P3 & 0 & 0 & 71 & 0 & 0 & 9 & 3 & 0 & 0 & 0 & 0 & 2 & 2 & 14 & 58 \\
\hline P5 & 12 & 7 & 0 & 6 & 50 & 2 & 9 & 0 & 3 & 0 & 0 & 2 & 3 & 7 & 163 \\
\hline P7 & 16 & 1 & 1 & 2 & 3 & 2 & 62 & 0 & 0 & 0 & 0 & 0 & 0 & 14 & 233 \\
\hline P9 & 33 & 0 & 0 & 17 & 17 & 0 & 0 & 0 & 17 & 0 & 0 & 0 & 17 & 0 & 6 \\
\hline P12 & 0 & 0 & 10 & 16 & 6 & 10 & 0 & 3 & 0 & 0 & 0 & 42 & 10 & 3 & 31 \\
\hline P13 & 5 & 1 & 7 & 2 & 7 & 6 & 7 & 0 & 0 & 0 & 0 & 4 & 45 & 16 & 85 \\
\hline P14 & 4 & 0 & 5 & 4 & 4 & 5 & 10 & 0 & 0 & 0 & 0 & 3 & 4 & 62 & 343 \\
\hline
\end{tabular}

whereas for P14 there is a bimodal (main modes in westerly and easterly directions) wind distribution. The average wind speed is similar for most patterns (4.5 to $5.8 \mathrm{~m} \mathrm{~s}^{-1}$ ). Only P9 appears different as it has an average wind speed of $7.2 \mathrm{~m} \mathrm{~s}^{-1}$ and also a markedly higher fraction of wind speeds $\geq 9 \mathrm{~m} \mathrm{~s}^{-1}$ (34\%) than the other patterns ( 7 to $19 \%$ ).

\subsection{Inter-annual variation in the distribution of patterns and wind erosion damage}

The temporal distribution of wind erosion days and the sum of re-sown area (for each erosion season) is shown in Fig. 10. The largest number of erosion days occurred in 1974 and 1984 when 7 and 6 re-sowing events were reported, respectively. In general, between 1 and 3 re-sowing events occur per erosion season. For most erosion weeks 1 or 2 days are singled out as erosion days, with the exception of an erosion week in mid-May 1981 that contains 6 erosion days. Fig. 10 shows the reported re-sown area for each year, ranging from 0 ha (in $1977 / 80 / 82 / 85 / 87 / 89$ ) to 821 ha (in 1984). Severe wind erosion (see Section 3.2) occurred in 1974 (4 events), 1978 (1 event), 1984 (2 events) and 1991 (1 event).

On average, the days with erosive patterns comprise about $75 \%$ of all 
Table 5. Wind statistics at Sturup, Scania, southern Sweden. For each erosive pattern, average wind speed, relative frequency of wind speeds $(U) \geq 9 \mathrm{~m} \mathrm{~s}^{-1}$ and relative frequency (\%) of the wind direction in 8 compass directions are shown. $N$ is the number of observations in each pattern. The most frequent wind direction for each pattern is indicated in bold

\begin{tabular}{|c|c|c|c|c|c|c|c|c|c|c|c|}
\hline \multirow{2}{*}{ Pattern } & \multirow{2}{*}{$N$} & \multirow{2}{*}{$\begin{array}{c}\text { Wind speed } \\
\text { Average } \\
\left(\mathrm{m} \mathrm{s}^{-1}\right)\end{array}$} & \multirow[b]{2}{*}{$\begin{array}{c}U \geq 9 \\
(\%)\end{array}$} & \multicolumn{8}{|c|}{ Wind direction } \\
\hline & & & & $\begin{array}{c}N \\
(\%)\end{array}$ & $\begin{array}{l}\mathrm{NE} \\
(\%)\end{array}$ & $\begin{array}{c}E \\
(\%)\end{array}$ & $\begin{array}{l}\mathrm{SE} \\
(\%)\end{array}$ & $\begin{array}{c}\mathrm{S} \\
(\%)\end{array}$ & $\begin{array}{l}\text { SW } \\
(\%)\end{array}$ & $\begin{array}{l}\text { W } \\
(\%)\end{array}$ & $\begin{array}{l}\text { NW } \\
(\%)\end{array}$ \\
\hline P1 & 5912 & 5.1 & 11 & 21 & 8 & 10 & 3 & 3 & 4 & 16 & 32 \\
\hline P3 & 3495 & 5.5 & 16 & 2 & 3 & 38 & 26 & 10 & 8 & 7 & 3 \\
\hline P5 & 4712 & 5.8 & 19 & 3 & 2 & 6 & 7 & 11 & 23 & 36 & 10 \\
\hline P7 & 4384 & 5.7 & 17 & 7 & 10 & 46 & 10 & 6 & 6 & 7 & 6 \\
\hline P9 & 2534 & 7.2 & 34 & 2 & 0 & 1 & 0 & 2 & 11 & 59 & 23 \\
\hline P12 & 3767 & 5.2 & 13 & 2 & 1 & 9 & 13 & 14 & 20 & 32 & 6 \\
\hline P13 & 3638 & 4.5 & 8 & 5 & 4 & 28 & 16 & 9 & 10 & 16 & 8 \\
\hline P14 & 6504 & 4.5 & 7 & 8 & 5 & 18 & 8 & 8 & 10 & 21 & 18 \\
\hline
\end{tabular}

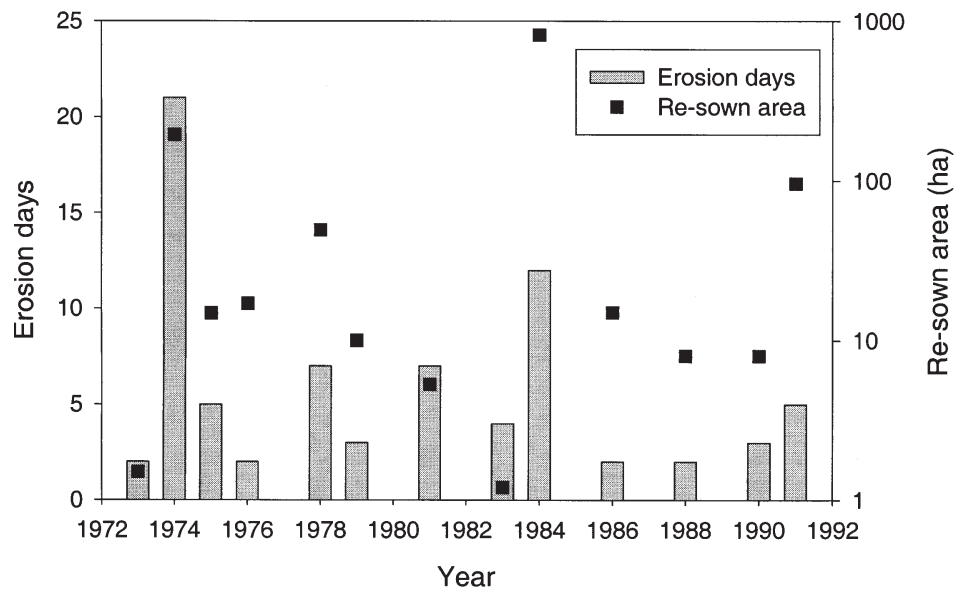

Fig. 10. Annual number of erosion days and sum of re-sown hectareage (1973-1991). Bars indicate the number of erosion days per erosion season (left hand $y$-axis) and square markers show the re-sown hectareage (ha) (right hand $y$-axis, log scale)

days during erosion seasons, with a maximum of $93 \%$ in 1985 and a minimum of $60 \%$ in 1989 (not shown). P7, which has the largest IES, occurs on average on $14 \%$ of all days (not shown). There is no obvious relationship between the pressure pattern distribution during the erosion seasons and the annual re-sown area in Fig. 10. This suggests that the occurrence of erosive pressure patterns during the erosion season is not, on its own, a good indicator for wind erosion. Important factors that also need to be considered are, for example, the wind speed conditions, vegetation cover and soil moisture.

\section{DISCUSSION}

The importance of different pressure patterns for wind erosion was investigated using 2 indices (the Index of Occurrence, IO, and the Index of Erosion
Severity, IES). These indices were based on the occurrence of the pressure patterns during the erosion season and the re-sown area of sugar beets, associated with each pressure pattern. We found that 2 particular pressure patterns have significantly higher IES than the other typical synoptic pressure patterns. These patterns have quite different qualities with respect to persistence, pressure distribution and wind characteristics.

Most moderate and severe wind erosion events $(74 \%)$, Table 3 , are associated with a pressure distribution describing an easterly flow over Scania (pattern P7, Fig. 8a), which agrees with previous studies of wind erosion in this region by Jönsson (1992). The important feature of this pattern is the advection of continental air mass over Scania. This air mass is drier and brings less precipitation than that of the westerly flow over Scania. Long spells of easterly wind flow thus greatly enhance the risk for wind erosion as they cause the surface to dry out.

In total, 14 pressure patterns were derived for an analysis of the large-scale spatial characteristics of surface pressure in the entire study region over northern Europe. The most important pattern, P7, is similar to the average regional-scale pressure pattern for the erosion days with easterly winds (Fig. 6a). The similarity between these patterns shows that the synoptic circulation during easterly erosion days is associated foremost with the pressure pattern P7. The main difference between P7 and the average pattern for the easterly erosion days is the position of the low pressure and the strength of the high pressure. As the pattern for P7 comprises all days classed as P7 during the study period, it is smooth compared with the pattern of the easterly erosion days.

The second important pressure pattern (P9, Fig. 8b) constitutes only $5 \%$ of the erosion days but has the 
potential to cause wind erosion due to strong westerly winds. This occurs despite westerly winds being associated with frontal precipitation that greatly reduce the risk for wind erosion. The pattern of P9 is similar to the average pressure pattern based on the westerly erosion days in Fig. 6b. This suggests that P9 is one of the important synoptic types when wind erosion occurs in Scania under westerly wind flow.

In short, both patterns (P7 and P9) describe a pressure gradient over Scania. In P7, the pressure gradient is rather weak, but in combination with high persistence of easterly winds (associated with dry conditions) an environment prone to wind erosion is produced. P9, on the other hand, is associated with a strong pressure gradient over Scania; hence high wind speeds there. Short-term storms are the erosive agents for P9. Depending on the disposition of the pressure systems in P7 and P9, the pressure gradient may be located over northern Europe, although slightly different from time to time. Hence, the easterly wind conditions that are associated with wind erosion in Scania could initiate erosion on soils susceptible to wind erosion in other cultivated regions in north-western Europe.

In this investigation we focused on major erosion events, i.e. events that were identified using records of sugar beet cropping in the Jordberga district. Sugar beet is, compared with other crops, particularly vulnerable to wind erosion. Firstly, the preparation of the seedbed, prior to sowing, increases the erodibility of the soil surface. Secondly, the growth rate of sugar beet is slow, which makes the sugar beet plant highly vulnerable to wind erosion for several weeks (Jönsson 1992). However, although sugar beet is sensitive to wind erosion, the records are based on re-sowing and only reflect events when wind erosion caused sufficient damage to the sugar beet crop for it to be resown. Thus, the analysis may have underestimated the total wind erosion in Jordberga as wind erosion events that were too short, too small or affected adjacent fields were not shown in the Jordberga records. For example, during May 7 and 8, 1985, extensive wind erosion was noted in the crop records but no damage to the sugar beets was recorded and consequently the event was not recorded as an erosion week. Thus, although the data provide a proxy for wind erosion, they are biased to reflect crop damage due to wind erosion on sugar beet crops, rather than reflecting the actual frequency and the full extent of wind erosion. Therefore, this study was concerned with the minimum frequency and areal extent of wind erosion in the area.

Wind erosion is a surface process that is related to other processes than wind alone, such as soil hydrological and surface bio-chemical processes (Shao 2000). Therefore, wind erosion, particularly on agri- cultural fields, is the result of several factors such as crop cover and the effects of agricultural practices, for example, the use of machines during soil surface preparation, sowing, harvesting etc., which do not necessarily have a straightforward relationship with climate. The complexity of wind erosion is evident when considering model estimations of wind erosion. An early method to estimate potential annual soil loss from agricultural fields was the 'wind erosion equation' (WEQ), a function that comprises factors such as soil erodibility, soil ridge roughness, climate, etc. (Woodruff \& Siddoway 1965). Zobeck et al. (2000) showed how the 'revised wind erosion equation' (RWEQ) could be used in combination with a 'geographic information system' (GIS) to scale-up wind erosion prediction from a field to a region. Models using a process-based, or a partly process-based, approach are the 'Wind Erosion Prediction System' (WEPS) (Nanney et al. 1993), the wind erosion model by Kruse (1994) and the 'Wind Erosion Assessment Model' (WEAM) (Shao et al. 1996).

Given the complexity of wind erosion processes and their controlling factors, it is unlikely that wind erosion in Jordberga relates to the synoptic circulation of northern Europe in a simple way. However, because factors like wind speed and precipitation have strong influences on the wind erosion process there must be a relationship between the weather situation and wind erosion. It is important to stress that wind provides the only positive forcing mechanism in the wind erosion process. Other factors, such as soil moisture, vegetation and crusting, can act against wind erosion taking place.

This work provides insights into how atmospheric circulation relates to wind erosion in Scania. A future perspective may be to use simulated MSLP from coupled global climate models (CGCMs) to assess the frequency of erosive pressure patterns in a climate change scenario. There are several models available that provide MSLP estimates. However, a recent evaluation of 15 different CGCMs within the coupled model inter-comparison project (CMIP1) showed considerable scatter among model results and between simulated and observed distribution of basic climate variables, e.g. surface air temperature, precipitation MSLP etc. (Lambert \& Boer 2001). In comparison with temperature and precipitation, simulated MSLP is generally more robust than precipitation but less so than temperature (Lambert \& Boer 2001), also shown by Räisänen (2000). As the CGCMs and regional mesoscale models (models with a higher resolution that focus on a particular region) are improved, new possibilities to investigate the erosivity of future climate may be aided by including not only improved simulated MSLP data but also simulated wind data. 


\section{CONCLUSIONS}

This study provides new insights into the linkage between large-scale circulation and wind erosion on cultivated land in Scania. There are 4 main conclusions that come out of this study:

(1) A pressure gradient that gives easterly winds over Scania occurs during the majority of erosion days in Scania and is associated with $74 \%$ of the total damage in the sugar beet district of Jordberga. When surface pressure is low over continental Europe and high over north-eastern Scandinavia, continental air is advected towards Scania. Such air masses are generally drier compared with maritime air masses, which are usually associated with frontal precipitation. Long spells of easterly winds allow the soil surface to dry, which makes it more susceptible to wind erosion.

(2) Other pressure patterns are also associated with wind erosion. A high IES value is obtained for a pattern that describes strong westerly flow over Scania. In this case, wind erosion is initiated by strong winds created by pronounced high pressure over the British Isles and a trough or cyclone over the northern parts of Scandinavia. With respect to the total number of erosion days, this pressure distribution is rare, being associated with 5 of the 75 wind erosion days, whilst the pressure pat- tern associated with easterly wind is responsible for 33 erosion days.

(3) Temporal variation of the pressure patterns and the recorded wind erosion shows that there is no obvious relationship between the distribution of pressure patterns during the erosion season and the re-sown area in Jordberga. This suggests that other factors, such as vegetation cover, precipitation and soil moisture, which largely decrease the erodibility of the soil surface, might be equally important to wind erosion in this region as the synoptic pressure distribution.

(4) The surface air pressure levels of north-eastern Scandinavia and south of Scania are crucial for the relationship between large-scale circulation and wind erosion in Scania. Equally important are the relative positions of the high and low pressure cells since the pressure gradient developed between the pressure action centres drives the surface wind.

Acknowledgements. This work is included in the EC RTD project WEELS (Wind Erosion on European Light Soils) with Contract No. ENV4-CT95-0129. Esben Almkvist at Göteborg University, Sweden, is acknowledged for helpful suggestions regarding the harmonics analysis, Adrian Chappell at Salford University for editing the English language and Kristina Persson at DANISCO for help with the wind erosion data for Jordberga.

Appendix 1. Sequence of patterns leading to and following the identified erosion days; date (YYYY-MM-DD), pattern number of the 3 days before the erosion day $(-3$ to $-1 \mathrm{~d})$, pattern number of the erosion day, pattern number of the 3 days after the erosion day $(+1$ to $+3 \mathrm{~d})$

\begin{tabular}{|c|c|c|c|c|c|c|c|}
\hline Date & $-3 \mathrm{~d}$ & $-2 \mathrm{~d}$ & $-1 \mathrm{~d}$ & Erosion day & $+1 \mathrm{~d}$ & $+2 \mathrm{~d}$ & $+3 d$ \\
\hline 19730506 & 13 & 13 & 6 & 6 & 5 & 5 & 12 \\
\hline 19730511 & 5 & 12 & 6 & 5 & 4 & 5 & 9 \\
\hline 19740428 & 2 & 1 & 7 & 7 & 7 & 7 & 7 \\
\hline 19740429 & 1 & 7 & 7 & 7 & 7 & 7 & 14 \\
\hline 19740430 & 7 & 7 & 7 & 7 & 7 & 14 & 14 \\
\hline 19740501 & 7 & 7 & 7 & 7 & 14 & 14 & 7 \\
\hline 19740504 & 7 & 14 & 14 & 7 & 7 & 1 & 14 \\
\hline 19740505 & 14 & 14 & 7 & 7 & 1 & 14 & 14 \\
\hline 19740508 & 7 & 1 & 14 & 14 & 14 & 3 & 3 \\
\hline 19740513 & 3 & 3 & 3 & 3 & 14 & 14 & 14 \\
\hline 19740514 & 3 & 3 & 3 & 14 & 14 & 14 & 14 \\
\hline 19740526 & 1 & 1 & 2 & 9 & 5 & 5 & 5 \\
\hline 19740527 & 1 & 2 & 9 & 5 & 5 & 5 & 13 \\
\hline 19740529 & 9 & 5 & 5 & 5 & 13 & 13 & 14 \\
\hline 19740530 & 5 & 5 & 5 & 13 & 13 & 14 & 12 \\
\hline 19740601 & 5 & 13 & 13 & 14 & 12 & 5 & 9 \\
\hline 19740603 & 13 & 14 & 12 & 5 & 9 & 14 & 6 \\
\hline 19740604 & 14 & 12 & 5 & 9 & 14 & 6 & 5 \\
\hline 19740605 & 12 & 5 & 9 & 14 & 6 & 5 & 5 \\
\hline 19740606 & 5 & 9 & 14 & 6 & 5 & 5 & 55 \\
\hline 19740609 & 6 & 5 & 5 & 5 & 5 & 1 & 1 \\
\hline 19740612 & 5 & 5 & 1 & 1 & 1 & 1 & 1 \\
\hline 19740613 & 5 & 1 & 1 & 1 & 1 & 1 & 14 \\
\hline 19750521 & 14 & 4 & 5 & 5 & 5 & 1 & 1 \\
\hline 19750522 & 4 & 5 & 5 & 5 & 1 & 1 & 7 \\
\hline 19750523 & 5 & 5 & 5 & 1 & 1 & 7 & 1 \\
\hline 19750529 & 1 & 2 & 1 & 7 & 7 & 7 & 7 \\
\hline
\end{tabular}


Appendix 1 (continued)

\begin{tabular}{|c|c|c|c|c|c|c|c|}
\hline Date & $-3 d$ & $-2 d$ & $-1 d$ & Erosion day & $+1 \mathrm{~d}$ & $+2 d$ & $+3 d$ \\
\hline 19750709 & 2 & 13 & 7 & 4 & 13 & 13 & 13 \\
\hline 19760528 & 14 & 14 & 14 & 14 & 14 & 14 & 14 \\
\hline 19760605 & 1 & 1 & 1 & 14 & 14 & 14 & 14 \\
\hline 19780507 & 13 & 7 & 7 & 7 & 7 & 1 & 1 \\
\hline 19780508 & 7 & 7 & 7 & 7 & 1 & 1 & 4 \\
\hline 19780514 & 4 & 7 & 7 & 7 & 1 & 14 & 14 \\
\hline 19780519 & 14 & 14 & 7 & 7 & 14 & 7 & 7 \\
\hline 19780523 & 14 & 7 & 7 & 7 & 7 & 2 & 2 \\
\hline 19780524 & 7 & 7 & 7 & 7 & 2 & 2 & 2 \\
\hline 19780525 & 7 & 7 & 7 & 2 & 2 & 2 & 2 \\
\hline 19790526 & 3 & 3 & 6 & 13 & 13 & 14 & 12 \\
\hline 19790604 & 4 & 2 & 7 & 7 & 7 & 1 & 1 \\
\hline 19790609 & 1 & 1 & 5 & 5 & 4 & 4 & 4 \\
\hline 19810511 & 3 & 7 & 7 & 7 & 7 & 14 & 3 \\
\hline 19810512 & 7 & 7 & 7 & 7 & 14 & 3 & 3 \\
\hline 19810513 & 7 & 7 & 7 & 14 & 3 & 3 & 14 \\
\hline 19810514 & 7 & 7 & 14 & 3 & 3 & 14 & 14 \\
\hline 19810516 & 14 & 3 & 3 & 14 & 14 & 3 & 14 \\
\hline 19810517 & 3 & 3 & 14 & 14 & 3 & 14 & 13 \\
\hline 19810522 & 14 & 13 & 13 & 13 & 12 & 3 & 3 \\
\hline 19830601 & 14 & 14 & 14 & 13 & 13 & 13 & 13 \\
\hline 19830602 & 14 & 14 & 13 & 13 & 13 & 13 & 2 \\
\hline 19830603 & 14 & 13 & 13 & 13 & 13 & 2 & 1 \\
\hline 19830610 & 1 & 1 & 5 & 4 & 4 & 4 & 4 \\
\hline 19840511 & 1 & 1 & 1 & 2 & 2 & 2 & 7 \\
\hline 19840512 & 1 & 1 & 2 & 2 & 2 & 7 & 7 \\
\hline 19840514 & 2 & 2 & 2 & 7 & 7 & 6 & 7 \\
\hline 19840520 & 7 & 7 & 14 & 7 & 7 & 7 & 7 \\
\hline 19840521 & 7 & 14 & 7 & 7 & 7 & 7 & 7 \\
\hline 19840522 & 14 & 7 & 7 & 7 & 7 & 7 & 7 \\
\hline 19840528 & 7 & 7 & 7 & 7 & 1 & 14 & 14 \\
\hline 19840529 & 7 & 7 & 7 & 1 & 14 & 14 & 3 \\
\hline 19840603 & 14 & 3 & 3 & 3 & 7 & 7 & 7 \\
\hline 19840604 & 3 & 3 & 3 & 7 & 7 & 7 & 7 \\
\hline 19840605 & 3 & 3 & 7 & 7 & 7 & 7 & 1 \\
\hline 19840613 & 1 & 1 & 4 & 12 & 4 & 4 & 1 \\
\hline 19860522 & 4 & 12 & 3 & 12 & 12 & 12 & 12 \\
\hline 19860525 & 12 & 12 & 12 & 12 & 12 & 12 & 5 \\
\hline 19880505 & 3 & 13 & 14 & 14 & 14 & 14 & 7 \\
\hline 19880508 & 14 & 14 & 14 & 7 & 4 & 1 & 14 \\
\hline 19900430 & 2 & 2 & 11 & 9 & 4 & 4 & 2 \\
\hline 19900528 & 1 & 1 & 1 & 1 & 4 & 13 & 14 \\
\hline 19900602 & 13 & 14 & 13 & 5 & 14 & 14 & 14 \\
\hline 19910520 & 1 & 2 & 1 & 5 & 9 & 9 & 1 \\
\hline 19910521 & 2 & 1 & 5 & 9 & 9 & 1 & 1 \\
\hline 19910522 & 1 & 5 & 9 & 9 & 1 & 1 & 1 \\
\hline 19910523 & 5 & 9 & 9 & 1 & 1 & 1 & 1 \\
\hline 19910604 & 1 & 7 & 7 & 7 & 14 & 6 & 7 \\
\hline
\end{tabular}

\section{LITERATURE CITED}

Åhman R (1974) Vinderosion i Sydskåne. (Wind erosion in southern Scania). Sven Geogr Årsb 50:232-240 (in Swedish with English summary)

Als C (1989) How to succeed in planting $900 \mathrm{~km}$ of shelterbelts per year in a small country like Denmark. In: Schwertmann U, Rickson RJ, Auerswald K (eds) Soil erosion protection measures in Europe: proceedings of the EC workshop on soil erosion protection, Freising, Germany, 24-26 May 1988. Soil Technology Series, Vol 1. Catena Verlag, Cremlingen-Destedt, p 25-27
Cattell RB (1966) The scree test for the number of factors. Multivar Behav Res 1:245-276

Compagnucci RH, Salles MA (1997) Surface pressure during the year over southern south America. Int J Climatol 17: 635-653

Davis RE, Kalkstein LS (1990) Development of an automated spatial synoptic climatological classification. Int J Climatol 10:769-794

Eppink LAAJ, Spaan WP (1989) Agricultural wind erosion control measures in the Netherlands In: Schwertmann U, Rickson RJ, Auerswald K (eds) Soil erosion protection measures in Europe: proceedings of the EC workshop on 
soil erosion protection, Freising, Germany, 24-26 May 1988. Soil Technology Series, Vol 1. Catena Verlag, Cremlingen-Destedt, p 1-13

Everitt B (1986) Cluster analysis. Published on behalf of the Social Science Research Council by Gower for the Social Science Research Council, Aldershot

Frakes B, Yarnal B (1997) A procedure for blending manual and correlation-based synoptic classifications. Int J Climatol 17:1381-1396

Hansen L (1989) Soil tillage, soil structure and soil erosion in Denmark. In: Schwertmann U, Rickson RJ, Auerswald K (eds) Soil erosion protection measures in Europe: proceedings of the EC workshop on soil erosion protection, Freising, Germany, 24-26 May 1988. Soil Technology Series, Vol 1. Catena Verlag, Cremlingen-Destedt, p 127-131

Hess P, Brezowsky H (1977) Katalog der Grosswetterlagen Europas (1881-1976). In: Berichte des Deutschen Wetterdienst, No. 113. Selbstverlag des Deutschen Wetterdienstes, Offenbach am Main

Hewitson B, Crane RG (1992) Regional climates in the GISS Global Circulation Model: synoptic-scale circulation. J Clim 5:1002-1011

Jönsson P (1992) Wind erosion on sugar beet fields in Scania, Southern Sweden. Agricult For Meteorol 62:141-157

Jönsson P (1994) Influence of shelter on soil sorting by wind erosion-a case study. Catena 22:35-47

Kaiser HF (1958) The Varimax criterion for analytic rotation in factor analysis. Psychometrica 23:187-200

Kidson JW (1994) An automated procedure for the identification of synoptic types applied to the New Zealand region. Int J Climatol 14:711-721

Kruse B (1994) Wind erosion model development. Ecol Model 75-76:289-298

Lamb HH (1950) Types and spells of weather around the year in the British Isles. Q J R Meteorol Soc 76:393-438

Lambert SJ, Boer GJ (2001) CMIP1 evaluation and intercomparison of coupled climate models. Clim Dyn 17:83-106

Linnaeus C (1751) Carl Von Linnés skånska resa, förrättad år 1749. Salvius, Stockholm (in Swedish)

Mattsson JO (1987) Vinderosion och klimatförändringar. Kommentarer till 1700-talets ekologiska kris i Skåne. (Wind erosion and climatic changes. Comments on the ecological crisis of Skåne during the 18th century). Sven Geogr Årsb 63:94-108 (in Swedish with English summary)

Mattsson JO, Nihlén T, Olesen F (1983) Vindens skadegörelse på åkermark i Skåne och Danmark. (Wind erosion in cultivated areas in Scania and Denmark). Sven Geogr Årsb 59: 34-59 (in Swedish with English summary)

Nanney RD, Fryrear DW, Zobeck TM (1993) Wind erosion prediction and control. Water Sci Technol 28:519-527

Nihlén T (1990) Eolian processes in southern Scandinavia and the Mediterranean area. Meddelanden från Lunds univer-

Editorial responsibility: Clare Goodess,

Norwich, United Kingdom sitets Geografiska institutioner, avh. 110. Lund University Press, Lund

Nihlén T, Åhman R (1991) Vinderosion i Skåne (Wind erosion of Skåne). Sven Geogr Årsb 59:34-59 (in Swedish with English summary)

North GR, Bell TL, Cahalan RF, Moeng FJ (1982) Sampling errors in the estimation of empirical orthogonal functions. Mon Weather Rev 110:699-706

Oldeman LR, Hakkeling RTA, Sombroek WG (1991) World map of human-induced soil degradation: an explanatory note. Global Assessment of Soil Degradation (GLASOD), ISRIC and United Nations Environment Programme (UNEP)/Winand Staring Centre-ISSS/Food and Agriculture Organization of the United Nations (FAO)-ITC. International Soil Reference and Information Centre, Wageningen

Räisänen J (2000) $\mathrm{CO}_{2}$-induced climate change in northern Europe: comparison of 12 CMIP2 experiments. SMHI Reports Meteorology Climatology No. 87, SMHI, Norrköping

Rasmusson G (1962) Sandstorm effects on arable land as seen on air photos. A study of a wind eroded area in the Vomb valley, Scania, Sweden. Lund Studies in Geography. Ser C. No. 3, Department of Geography, CWK Gleerup, Lund

Richman MB (1986) Rotation of principal components. J Climatol 6:293-335

Riksen MJPM, De Graaff J (2001) On-site and off-site effects of wind erosion on European light soils. Land Degrad Dev 12:1-11

Schultz M, Stattegger K (1997) SPECTRUM: spectral analysis of unevenly spaced paleoclimatic time series. Comput Geosci 23:929-945

Shao Y (2000) Physics and modelling of wind erosion. Kluwer Academic Publishers, Dordrecht

Shao Y, Raupach MR, Leys JF (1996) A model for predicting aeolian sand drift and dust entrainment on scales from paddock to region. Aust J Soil Res 34:309-342

Slonosky VC, Jones PD, Davies TD (2000) Variability of the surface atmospheric circulation over Europe, 1774-1995. Int J Climatol 20:1875-1897

White D, Richman MB, Yarnal B (1991) Climate regionalization and rotation of principal components. Int J Climatol 11:1-25

Woodruff NP, Siddoway FH (1965) A wind erosion equation. Soil Sci Soc Am Proc 29:602-608

von Storch H, Zwiers FW (1999) Statistical analysis in climate research. Cambridge University Press, Cambridge

Yarnal B (1993) Synoptic climatology in environmental analysis. Belhaven Press, London

Zobeck TM, Parker NC, Haskell S, Guoding K (2000) Scaling up from field to region for wind erosion prediction using a field-scale wind erosion model and GIS. Agricult Ecosyst Environ 82:247-259

Submitted: November 30, 2001; Accepted: July 9, 2002

Proofs received from author(s): November 13, 2002 